\title{
Assessment of Undiscovered Gas Resources in Upper Devonian to Lower Cretaceous Strata of the Western North Slope, Alaska, 2021
}

Using a geology-based assessment methodology, the U.S. Geological Survey estimated a mean of 1,407 billion (1.4 trillion) cubic feet of gas in conventional accumulations in Upper Devonian to Lower Cretaceous strata of the western North Slope, Alaska.

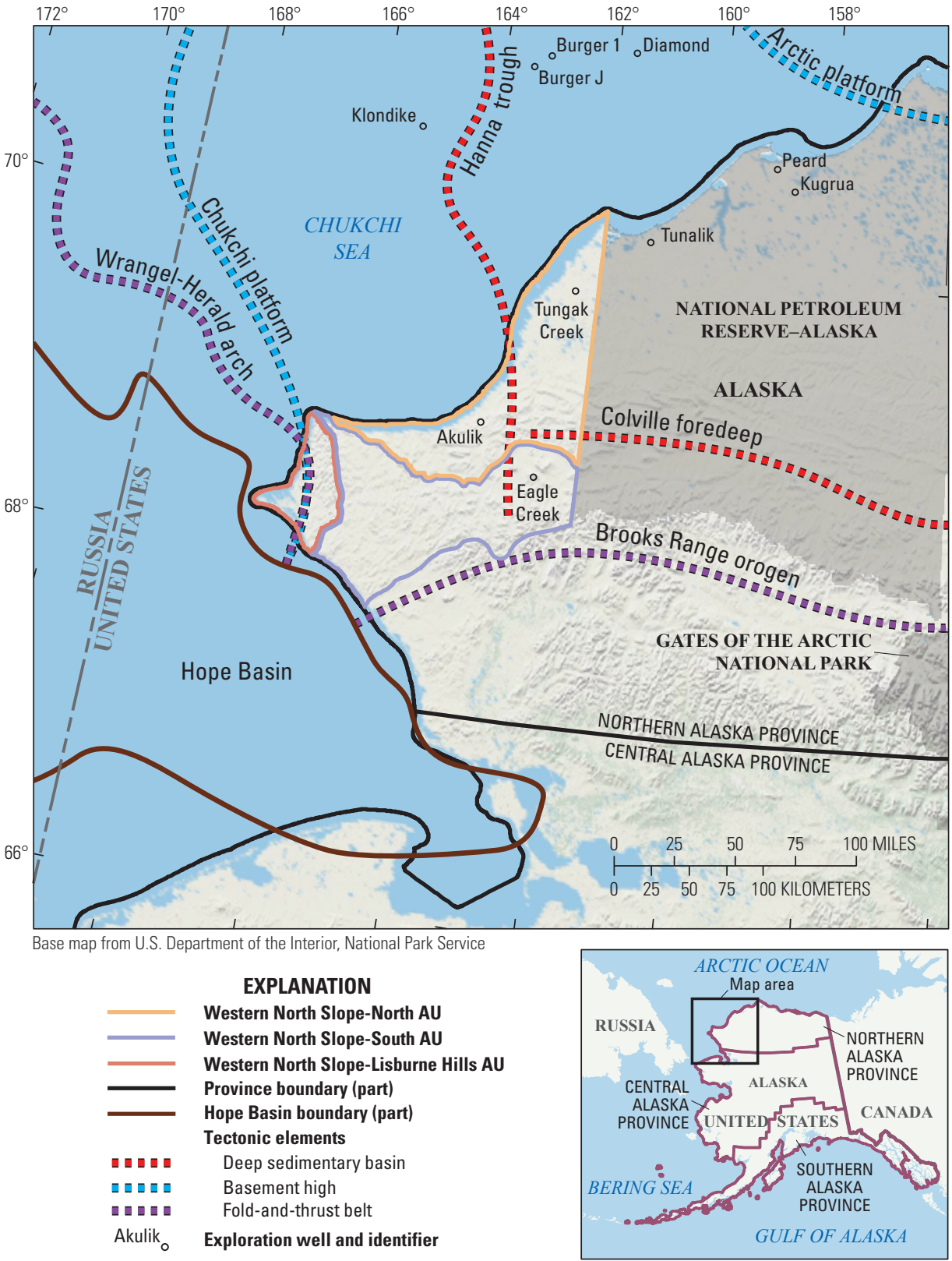

\section{Introduction}

The U.S. Geological Survey (USGS) assessed the potential for undiscovered, technically recoverable gas resources in conventional accumulations in Upper Devonian to Lower Cretaceous strata of the western North Slope of Alaska, including adjacent State waters (fig. 1). The western North Slope lies north of the Brooks Range, west of the National Petroleum Reserve-Alaska (NPR-A), and east of the Chukchi Sea. The western North Slope was included in previous assessments of (1) conventional resources of the Cretaceous Nanushuk and Torok Formations in the NPR-A and adjacent areas (Houseknecht and others, 2017) and (2) continuous resources of the entire North Slope (Houseknecht and others, 2012). Thus, rocks considered in this assessment are limited to strata older than the Torok Formation and younger than the acoustic basement (fig. 2).

The assessment area contains sparse subsurface data, including three exploration wells (fig. 1) drilled between 1978 and 1982 and about 500 miles (800 kilometers) of vintage (1970-1971) two-dimensional (2D) seismic data. These were supplemented by geologic maps of the western North Slope and adjacent areas (for example, Mull and others, 2000). Additional well and 2D seismic data from the NPR-A and Chukchi Sea were used to construct a more robust geologic framework for the assessment.

Figure 1. Map showing the location of three assessment units (AUs) in the western North Slope of Alaska, Federal land boundaries (including the National Petroleum Reserve-Alaska [NPR-A]), and pertinent exploration wells. The Akulik and Tungak Creek wells reached total depth in the Torok Formation, whereas the Eagle Creek well reached total depth in the Mount Kelly Graywacke Tongue of Fortress Mountain Formation (fig. 2). Only wells within 80 miles of the assessment area also penetrating deeper than the Torok Formation are shown. 


\section{Geological Framework and Assessment Units}

The assessment area lies at the intersection of several tectonic domains (fig. 1) ranging in age from Late Devonian to Paleogene (Moore and others, 2002; Sherwood and others, 2002; Dumoulin and others, 2013; Homza and Bergman, 2019; Houseknecht, 2019). The origin and effects of these domains are described here. (1) The Hanna trough formed as a failed rift basin during the Late Devonian, comprising a series of north-south-oriented grabens. (2) Following cessation of rifting in the Mississippian, the Hanna trough evolved into a broad sag basin between high-standing basement rocks of the Chukchi platform and Arctic platform. Exposures of Mississippian to Pennsylvanian strata in the western Brooks Range suggest the Hanna trough rift and sag basins extend southward through the assessment area. (3) The southern margin of the assessment area was subjected to a Jurassic to Early Cretaceous, north-vergent pulse of Brooks Range tectonism. Associated tectonic loading induced flexural subsidence forming the Colville foredeep, whose western end merges with the southern Hanna trough in the assessment area. (4) The westernmost part of the assessment area (Lisburne Hills) was deformed in the Early Cretaceous (Aptian) as the north- to northeast-vergent Wrangel-Herald arch fold-and-thrust belt rode up and over the southern extent of the Chukchi platform. (5) A Paleogene pulse of north-vergent Brooks Range tectonism deformed much of the assessment area, forming thrust-fault imbricates of older rocks in the south and forming broad folds in the Torok and Nanushuk Formations in the north. (6) Extensional faulting formed the Hope Basin, thereby burying the southwestern extents of the Wrangel-Herald arch, Chukchi platform, and Brooks Range orogen beneath thick Eocene and younger sediment.

One implication of this geological history is certain strata in the Hanna trough sag basin include deeper water and more distal deposits than coeval strata elsewhere on the North Slope. Petroleum source rocks occur in the Triassic Otuk-Shublik Formation and Jurassic to Lower Cretaceous Kingak Shale, as is true regionally (fig. 2). Additionally, the Kugrua, Tunalik, and Klondike wells (fig. 1) penetrated source rocks in the upper Sadlerochit Group (fig. 2), whereas coeval strata in Prudhoe Bay and other oil fields of the central North Slope are high-quality reservoir rocks. The geological history of the Hanna trough rift and sag basins and Colville foredeep also resulted in deeper burial and higher thermal maturity of Upper Devonian to Lower Cretaceous strata in the assessment area compared to coeval strata across much of the North Slope. Consequently, all strata considered in this assessment have been exposed to temperatures generally unfavorable for the preservation of oil.

Rich and originally oil-prone source rocks occur in the Ellesmerian, Beaufortian, and Brookian (Hue Shale, fig. 2) sequences in the assessment area. Wells drilled in and near the assessment area have encountered only gas. For example, the Tunalik exploration well, located less than 20 miles east of the northern part of the assessment area, penetrated more than 9,000 feet of upper Kingak Shale through Lisburne Group strata and found only overpressured gas. Available chemical analyses of recovered gas are insufficient to determine from which source rock the gas was generated. In the absence of definitive

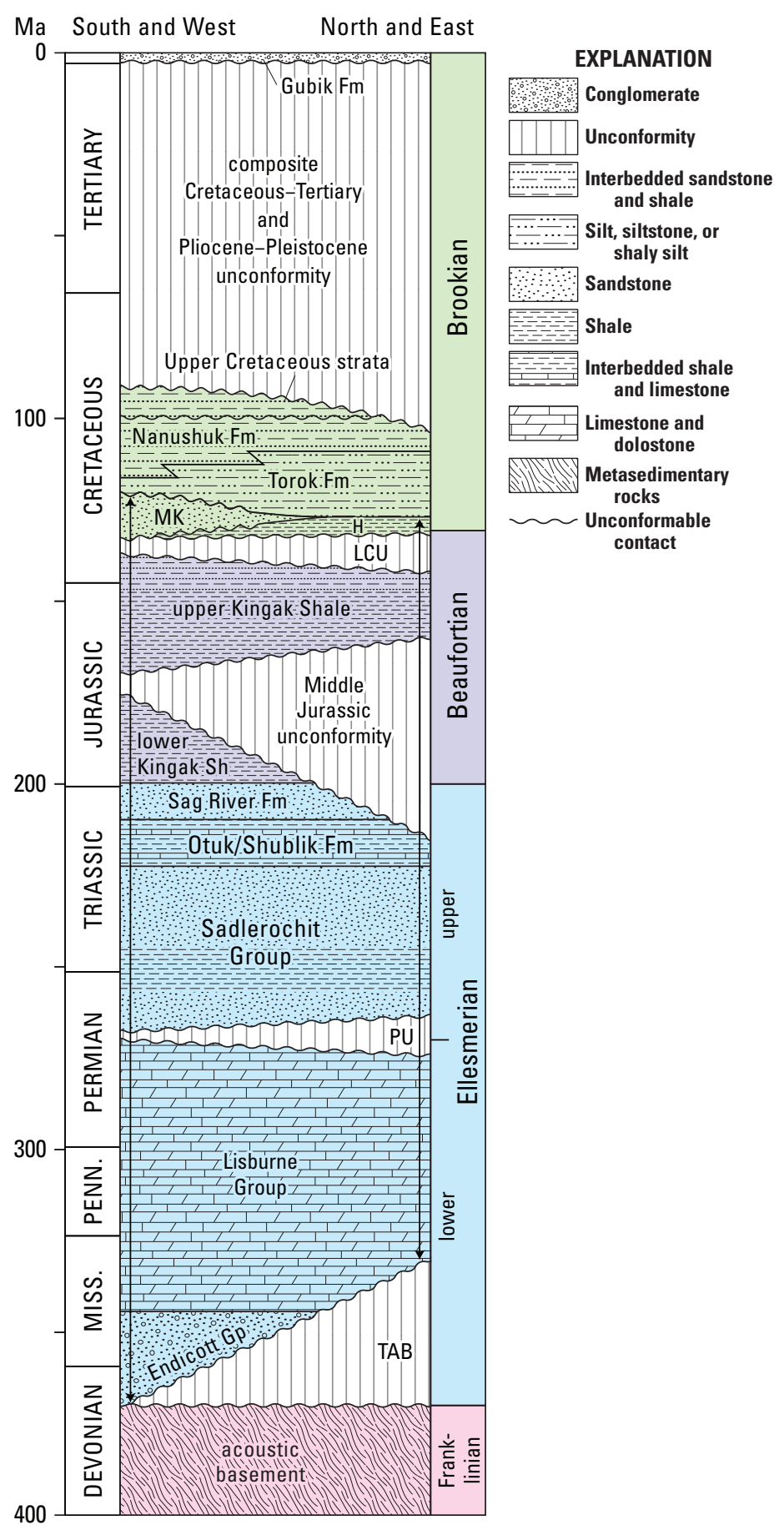

Figure 2. Generalized chronostratigraphy of the western North Slope assessment area. Age and geologic period at left (Mississippian [MISS.] and Pennsylvanian [PENN.]), main stratigraphic names on graphic column, and tectonostratigraphic sequence names at right. Double headed arrows show strata assessed. Fm, formation; Gp, Group; Sh, Shale; H, pebble shale unit and Hue Shale; Ma, mega annum; LCU, Lower Cretaceous unconformity; MK, Mount Kelly Graywacke Tongue of Fortress Mountain Formation; PU, Permian unconformity; TAB, top acoustic basement unconformity. Figure adapted from Sherwood and others (2002) and Craddock and Houseknecht (2016), with original contributions. 
data, we consider the western North Slope to be part of the Arctic Alaska Composite Total Petroleum System (Bird and Houseknecht, 2011).

Three assessment units (AUs) were defined based on geology (fig. 1). The Western North Slope-North AU is characterized by a generally uniform dip to the southsouthwest. Depth to the top of assessed strata ranges from about 10,000 feet in the north to about 23,000 feet in the south. Although most of the AU displays folds at the surface, these are accommodated by thrust faults detached in the lower part of the Torok Formation and the assessed strata display only minor deformation. Therefore, most trap geometries likely are stratigraphic. Petrophysical analysis of wells outside the AU indicates porosity of potential reservoirs is low, typically less than 10 percent.

The Western North Slope-South AU is characterized by significant thrust faulting and folding, which occurred during the Paleogene pulse of Brooks Range tectonism (Moore and others, 2015; Craddock and others, 2018). The resulting imbricated structures form thick, structural trap geometries extending from surface exposures to the top of acoustic basement at depths ranging up to 30,000 feet. Petrophysical analysis of the Eagle Creek well within the AU indicates porosity of potential reservoirs is low, typically less than 5 percent.

The Western North Slope-Lisburne Hills AU is characterized by a shallow basement, the southern extension of the Chukchi platform, and both basement and overlying strata are characterized by significant thrust faulting and folding (Moore and others, 2002; Homza and Bergman, 2019). The imbricate structures appear to form relatively thin structural trap geometries, and timing between petroleum generation and trap formation is considered poor.

\section{Undiscovered Resources Summary}

Undiscovered, technically recoverable resources in conventional accumulations of a minimum size of 30 billion cubic feet of gas (BCFG), similar to 5 million barrels of oil (MMBO), were estimated for the western North Slope of Alaska. Input data and results of the USGS assessment are shown in tables 1 and 2. The fully risked, estimated mean total resource for the western North Slope includes 1,407 BCFG with an $\mathrm{F} 95$ to $\mathrm{F} 5$ range from 0 to $5,632 \mathrm{BCFG}$, and 10 million barrels of natural gas liquids (MMBNGL) with an F95 to F5 range from 0 to 39 MMBNGL. Oil resources were not quantitatively assessed, because the probability for the existence of at least one accumulation of the minimum size was considered negligible.

Resources assessed in the Western North Slope-North AU include fully risked, estimated mean gas resources of 1,274 BCFG with an F95 to F5 range from 0 to 4,865 BCFG and 9 MMBNGL with an F95 to F5 range from 0 to 34 MMBNGL. Resources assessed in the Western North Slope-South AU include fully risked, estimated mean resources of $133 \mathrm{BCFG}$, with an F95 to F5 range from 0 to 767 BCFG and 1 MMBNGL with an F95 to F5 range from 0 to 5 MMBNGL. No quantitative assessment was conducted in the Western North Slope-Lisburne Hills AU because the probability for the existence of at least one accumulation of the minimum size was considered negligible.

\section{Acknowledgment}

We thank Ken Bird for constructive insights regarding western North Slope geology.

Table 1. Key input data for two conventional assessment units in the western North Slope of Alaska.

[Gray shading indicates not applicable. AU, assessment unit; BCFG, billion cubic feet of gas]

\begin{tabular}{|l|c|c|c|c|c|c|c|c|}
\hline \multicolumn{1}{|c}{$\begin{array}{c}\text { Assessment input data- } \\
\text { Conventional AUs }\end{array}$} & \multicolumn{3}{c|}{ Mestern North Slope-North AU } & \multicolumn{3}{c|}{ Western North Slope-South AU } \\
\cline { 2 - 12 } & Minimum & Median & Maxium & $\begin{array}{c}\text { Calculated } \\
\text { mean }\end{array}$ & Minimum & Median & $\begin{array}{c}\text { Maximum } \\
\text { Calculated } \\
\text { mean }\end{array}$ \\
\hline Number of gas fields & 1 & 12 & 36 & 12.8 & 1 & 5 & 40 & 6.2 \\
\hline Size of gas fields (BCFG) & 30 & 60 & 10,000 & 185.7 & 30 & 42 & 6,000 & 107.8 \\
\hline AU probability & 0.54 & & & & 0.2 & & & \\
\hline
\end{tabular}

Table 2. Results for three conventional assessment units in the western North Slope of Alaska.

[Results shown are fully risked estimates. F95 represents a 95-percent chance of at least the amount tabulated; other fractiles are defined similarly. Gray shading indicates not applicable. AU, assessment unit; BCFG, billion cubic feet of gas; NGL, natural gas liquids; MMBNGL, million barrels of natural gas liquids]

\begin{tabular}{|c|c|c|c|c|c|c|c|c|c|c|c|c|c|c|}
\hline \multirow{3}{*}{$\begin{array}{l}\text { Total petroleum system and } \\
\text { assessment units (AUs) }\end{array}$} & \multirow{3}{*}{$\begin{array}{c}\text { AU } \\
\text { prob- } \\
\text { ability }\end{array}$} & \multirow{3}{*}{$\begin{array}{c}\text { Accum- } \\
\text { ulation } \\
\text { type }\end{array}$} & \multicolumn{12}{|c|}{ Total undiscovered resources } \\
\hline & & & \multicolumn{4}{|c|}{ Oil (MMBO) } & \multicolumn{4}{|c|}{ Gas (BCFG) } & \multicolumn{4}{|c|}{ NGL (MMBNGL) } \\
\hline & & & F95 & F50 & F5 & Mean & F95 & F50 & F5 & Mean & F95 & F50 & F5 & Mean \\
\hline \multicolumn{15}{|c|}{ Arctic Alaska Composite Total Petroleum System } \\
\hline Western North Slope-North AU & 0.54 & Gas & & & & & 0 & 652 & 4,865 & 1,274 & 0 & 5 & 34 & 9 \\
\hline Western North Slope-South AU & 0.2 & Gas & & & & & 0 & 0 & 767 & 133 & 0 & 0 & 5 & 1 \\
\hline Western North Slope-Lisburne Hills AU & 0.02 & Gas & \multicolumn{12}{|c|}{ Not quantitatively assessed } \\
\hline Total undiscovered conventional resources & & & & & & & 0 & 652 & 5,632 & 1,407 & 0 & 5 & 39 & 10 \\
\hline
\end{tabular}




\section{References Cited}

Bird, K.J., and Houseknecht, D.W., 2011, Geology and petroleum potential of the Arctic Alaska petroleum province, chap. 32 of Spencer, A.M., Embry, A.F., Gautier, D.L., Stoupakova, A.V., and Sørensen, K., eds., Arctic petroleum geology: The Geological Society of London, Memoir v. 35, p. 485-499.

Craddock, W.H., and Houseknecht, D.W., 2016, CretaceousCenozoic burial and exhumation history of the Chukchi Shelf, offshore Arctic Alaska: American Association of Petroleum Geologists Bulletin, v. 100, no. 01, p. 63-100, accessed December 11, 2020, at https://doi.org/10.1306/09291515010.

Craddock, W.H., Moore, T.E., O’Sullivan, P., Potter, C.J., and Houseknecht, D.W., 2018, Late Cretaceous-Cenozoic exhumation of the western Brooks Range, Alaska, revealed from apatite fission track data: Tectonics, v. 37, no. 12, p. 4714-4751, accessed December 11, 2020, at https://doi.org/ 10.1029/2018TC005282.

Dumoulin, J., Johnson, C., Slack, J., Bird, K., Whalen, M., Moore, T., Harris, A., and O'Sullivan, P., 2013, Carbonate margin, slope, and basin facies of the Lisburne Group (CarboniferousPermian) in northern Alaska, in Verwer, K., Playton, T., and Harris, P., eds., Deposits, architecture, and controls of carbonate margin, slope, and basin systems - Society for Sedimentary Geology Special Publication 105 p. 211-236.

Homza, T.X., and Bergman, S.C., 2019, A geologic interpretation of the Chukchi Sea Petroleum Province-Offshore Alaska, USA: American Association of Petroleum Geologists Memoir 119, p. 1-330, accessed December 11, 2020, at https://doi.org/ 10.1306/AAPG119.

Houseknecht, D.W., 2019, Evolution of the Arctic Alaska sedimentary basin, in Miall, A.D., ed., The sedimentary basins of the United States and Canada: Elsevier, p. 719-745, accessed December 11, 2020, at https://doi.org/10.1016/B978-0-44463895-3.00018-8.

Houseknecht, D.W., Lease, R.O., Schenk, C.J., Mercier, T.J., Rouse, W.A., Jarboe, P.J., Whidden, K.J., Garrity, C.P., Lewis, K.A., Heller, S.J., Craddock, W.H., Klett, T.R., Le, P.A., Smith, R.A., Tennyson, M.E., Gaswirth, S.B., Woodall, C.A., Brownfield, M.E., Leathers-Miller, H.M., and Finn, T.M.,
2017, Assessment of undiscovered oil and gas resources in the Cretaceous Nanushuk and Torok Formations, Alaska North Slope, and summary of resource potential of the National Petroleum Reserve in Alaska, 2017: U.S. Geological Survey Fact Sheet 2017-3088, 4 p., accessed December 11, 2020, at https://doi.org/10.3133/fs20173088.

Houseknecht, D.W., Rouse, W.A., Garrity, C.P., Whidden, K.J., Dumoulin, J.A., Schenk, C.J., Charpentier, R.R., Cook, T.A., Gaswirth, S.B., Kirschbaum, M.A., and Pollastro, R.M., 2012, Assessment of potential oil and gas resources in source rocks of the Alaska North Slope, 2012: U.S. Geological Survey Fact Sheet 2012-3013, 2 p., accessed December 11, 2020, at https://doi.org/10.3133/fs20123013.

Moore, T.E., O'Sullivan, P.B., Potter, C.J., and Donelick, R.A., 2015, Provenance and detrital zircon geochronologic evolution of lower Brookian foreland basin deposits of the western Brooks Range, Alaska, and implication for early Brookian tectonism: Geosphere, v. 11, no. 1, p. 93-122, accessed December 11, 2020, at https://doi.org/10.1130/GES01043.1.

Moore, T.E., Dumitru, T.A., Adams, K.E., Witebsky, S.N., and Harris, A.G., 2002, Origin of the Lisburne Hills-Herald arch structural belt - Stratigraphic, structural, and fission track evidence from the Cape Lisburne area, northwestern Alaska, in Miller, E.L., Grantz, A., and Klemperer, S.L., eds., Tectonic evolution of the Bering Shelf-Chukchi Sea-Arctic Margin and adjacent landmasses: Geological Society of America Special Paper 360, p. 77-109, accessed December 11, 2020, at https://doi.org/10.1130/0-8137-2360-4.77.

Mull, C.G., Harris, E.E., Reifenstuhl, R.R., and Moore, T.E., 2000, Geologic map of the Coke basin-Kukpowruk River area, De Long Mountains D-2 and D-3 quadrangles, Alaska: Alaska Division of Geological \& Geophysical Surveys Report of Investigation 2000-2, 1 sheet, scale 1:63,360, accessed December 11, 2020, at https://doi.org/10.14509/2737.

Sherwood, K.W., Johnston, P.P., Craig, J.D., Zerwick, S.A., Lothamer, R.T., Thurston, D.K., and Hurlbert, S.B., 2002, Structure and stratigraphy of the Hanna trough, U.S. Chukchi shelf, Alaska, in Miller, E., Grantz, A., and Klemperer, S., eds., Tectonic evolution of the Bering ShelfChukchi Sea-Arctic Margin and adjacent landmasses: Geological Society of America Special Paper 360, p. 39-66. [Also available at https://doi.org/10.1130/0-8137-2360-4.39.]

\section{For More Information}

Assessment results are also available at the USGS Energy Resources Program website at https://energy.usgs.gov.

\section{Western Assessment Team}

David W. Houseknecht, Tracey J. Mercier, Christopher J. Schenk, Thomas E. Moore, William A. Rouse, Julie A. Dumoulin, William H. Craddock, Richard O. Lease, Palma J. Botterell, Margaret M. Sanders, Rebecca A. Smith, Christopher D. Connors, Christopher P. Garrity, Katherine J. Whidden, Jared T. Gooley, John W. Counts, Joshua H. Long, and Christina A. DeVera 